\title{
Pengembangan modul berbasis keterampilan proses sains sebagai bahan ajar dalam pembelajaran biologi
}

\author{
Laila Puspita \\ Program Studi Pendidikan Biologi, Fakultas Tarbiyah dan Keguruan, Universitas Islam Negeri Raden \\ Intan Lampung. Jalan Letkol Endro Suratmin Sukarame, Kota Bandar Lampung, Indonesia, 35131 \\ *Corresponding Author. Email: lailapuspita@radenintan.ac.id
}

Received: 21 December 2018; Revised: 31 January 2019; Accepted: 30 April 2019

\begin{abstract}
Abstrak
Penelitian ini bertujuan untuk mengetahui kemenarikan dan kelayakan dari modul berbasis keterampilan proses sains pada pembelajaran Biologi dalam materi sistem ekskresi pada manusia. Penelitian ini merupakan penelitian Research and Development (R\&D) miliknya Bord and Gall. Adapun Teknik pengumpulan data menggunakan nontes berupa angket, wawancara, observasi. Instrumen yang digunakan berupa angket ahli materi, angket ahli desain media dan angket ahli bahasa dan angket respon peserta didik. Modul yang sudah dikembangkan divalidasi oleh 2 ahli materi, 2 ahli desain media, dan 2 ahli bahasa untuk mengetahui kelayakan produk. Hasil penilaian kelayakan modul berbasis keterampilan proses sains oleh ahli materi sebesar 92,5\% dalam kategori sangat layak, penilaian oleh ahli desain sebesar 78,5\% dalam kategori sangat layak, penilaian oleh ahli bahasa sebesar 90,5\% dalam kategori sangat layak. Hasil respon peserta didik memperoleh $74 \%$ dalam kategori menarik. Berdasarkan hasil penelitian ini dapat disimpulkan modul berbasis keterampilan proses sains pada pembelajaran Biologi layak dan menarik digunakan dalam materi sistem ekskresi pada manusia.
\end{abstract}

Kata Kunci: bahan ajar; proses sains; sistem ekskresi

\section{Module development based on science process skills as teaching materials in biological learning}

\begin{abstract}
This study aims to determine the attractiveness and feasibility of modules based on science process skills in Biology learning in excretory system material in humans. This research is a Research and Development $(R \& D)$ study of Bord and Gall. The data collection techniques using nontes in the form of questionnaires, interviews, observations. The instruments used were questionnaires for material experts, questionnaires for media design experts and questionnaires for linguists and student response questionnaires. The modules that have been developed are validated by 2 material experts, 2 media design experts, and 2 linguists to find out the feasibility of the product. The results of the feasibility assessment module based on science process skills by material experts is $92.5 \%$ in the very feasible category, the assessment by design experts is $78.5 \%$ in the very feasible category, the assessment by linguists is $90.5 \%$ in the very feasible category. The students' response results gained $74 \%$ in the interesting category. Based on the results of this study it can be concluded that the module based on science process skills in Biology learning is feasible and interesting to use in excretion system material in humans.
\end{abstract}

Keywords: teaching materials; science process; excretion systems

How to Cite: Puspita, L. (2019). Pengembangan modul berbasis keterampilan proses sains sebagai bahan ajar dalam pembelajaran biologi. Jurnal Inovasi Pendidikan IPA, 5(1), $79-88$. doi:https://doi.org/10.21831/jipi.v5i1.22530

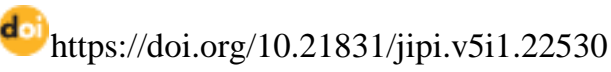

\section{PENDAHULUAN}

Salah satu tujuan penyusunan modul adalah menyediakan bahan ajar yang sesuai dengan tuntunan kurikulum dengan mempertimbangkan kebutuhan peserta didik, yakni bahan ajar yang sesuai dengan karakteristik materi ajar dan karakteristik peserta didik. Modul pembelajaran merupakan bahan ajar yang disusun secara sistematis dan menarik yang mencakup isi materi, metode dan evaluasi yang dapat digunakan 
secara mandiri untuk mencapai kompetensi yang diharapkan (Anwar, 2010; I. Dewi \& Lisiani, 2015; Nafaida, Halim, \& Rizal, 2015; Subekti, 2018). Pengembangan modul berbasis keterampilan proses sains masih perlu dikembangkan untuk mengasah keterampilan proses sains peserta didik (P. Y. A. Dewi \& Primayana, 2019).

Peserta didik memiliki kemampuan dan kecepatan dalam penyerapan materi pembelajaran sehingga dibutuhkan lebih dari buku untuk dapat membimbing peserta didik untuk menjadi aktif belajar secara mandiri. Selama ini proses pembelajaran di dalam kelas juga kurang melibatkan interaksi peserta didik karena beberapa hal salah satunya karena keterbatasan waktu sehingga penddik lebih cenderung menggunakan pendekatan teacher centered. Sedangkan tuntutan kurikulum 2013 mengharuskan pendidik untuk menggunakan pendekatan student centered yang membutuhkan waktu. Keterbatasan waktu di dalam kelas dapat penuhi dengan proses pembelajaran yang dilakukan secara mandiri oleh masingmasing peserta didik dengan bantuan modul pembelajaran yang sudah didesain sesuai dengan tujuan pembelajaran. Modul yang baik minimal memuat tujuan pembelajaran, materi/ substansi belajar, dan evaluasi (Anggraini \& Sukardi, 2015; Noto, 2014; Shinta, 2014; Widyasari, Sukarmin, \& Sarwanto, 2015).

Pembelajaran Biologi di MTsNegeri 2 Bandar Lampung: (1) selama ini peserta didik hanya berpegang pada buku paket untuk dijadikan sumber belajar. Buku bersifat umum, karena dibuat untuk keperluan umum, sehingga peserta didik memerlukan bantuan orang lain seperti guru untuk menjelaskan isi buku tersebut. Berdasarkan sifat penyajiannya, buku cenderung informatif dan sajian materi ajarnya memiliki cakupan luas dan umum, sehingga komunikasi berlangsung satu arah dan peserta didik memiliki kecenderungan untuk pasif; (2) modul pembelajaran berbasis keterampilan proses sainsbelum pernah digunakan sebagai bahan ajar peserta didik; (3) Pembelajaran dikelas masih cenderung bersifat teacher centere; (4) Peserta didik tidak terlatih dalam pembelajaran berbasis keterampulan proses sains; (5) Peserta didik kurang mendapatkan sumber pembelajaran yang bervariasi.

Biologi sebagai salah satu bidang sains menyediakan berbagai pengalaman belajar untuk memahami produk dan proses sains serta diharapkan dengan mempelajari sains akan terbentuk juga keterampilan proses sains. Karena proses sains merupakan keseluruhan keterampil- an yang terarah (baik kognitif dan psikomotor) yang dapat digunakan untuk menemukan suatu konsep, prinsip atau teori untuk mengembangkan konsep yang telah ada sebelumnya atau untuk melakukan penyangkalan terhadap adanya penemuan (Marjan, Arnyana, \& Setiawan, 2014; Rosidi, 2016; Sasanti, Hartini, \& Mahardika, 2017). Sains sebagai produk berarti dalam mempelajari sains terdapat fakta-fakta, hukumhukum, prinsip-prinsip dan teori-teori yang sudah diterima kebenarannya.

Dengan mengembangkan keterampilanketerampilan seperti perolehan yang didapatkan dari sebuah proses, peserta didik akan mampu menemukan dan mengembangkan sendiri fakta dan konsep serta menumbuhkan dan mengembangkan sikap dan nilai yang dituntut. Bahan pembelajaran yang sistematis dan menarik diharapkan dapat memotivasi peserta didik untuk belajar secara mandiri di luar kelas. Sehingga proses pembelajaran akan tetap berlangsung sampai peserta didik dapat menguasai materi yang dipaparkan.

\section{METODE}

Penelitian ini merupakan penelitian menggunakan model pengembangan yang dikembangkan oleh (Gall, Gall, \& Borg, 2007), yaitu terdiri dari sepuluh langkah: (1) potensi dan masalah; (2) mengumpulkan informas; (3) desain produk; (4) validasi desain; (5) perbaikan desain; (6) uji coba produk; (7) revisi produk; (8)uji coba pemakaian; (9) revisiproduk; dan (10) pembuatan produk masa (Ainin, 2013; Putra \& Anggraini, 2016).

Pada penelitian ini langkah-langkah pengembangan modul biologi berbasis keterampilan proses sains disederhanakan menjadi tujuh tahapan (Akbar \& Komarudin, 2018; Rodiawati \& Komarudin, 2018; Septina, Farida, \& Komarudin, 2018). Pembatasan langkah pengembangan dilakukan karena tujuan penelitian ini untuk mengetahui kelayakan dan kemenarikan terhadap modul biologi yang dikembangkan dengan mempertimbangkan keterbatasan waktu dan sumber daya yang dimiliki peneliti, maka penenlitian hanya menggunakan 7 tahap pengembangan oleh Borg \& Gall, yaitu (1) potensi dan masalah, (2) pengumpulan data; (3) desain produk; (4) validasi desain; (5) revisi produk; (6) uji coba produk; dan (7) revisi produk.

Teknik pengumpulan data yang digunakan adalah nontes berupa angket, wawancara dan observasi. Angket terdiri dari angket ahli materi, 


\section{Jurnal Inovasi Pendidikan IPA, 5 (1), 2019 - 81}

Laila Puspita

angket ahli desain media dan angket ahli bahasa, dan angket respon peserta didik.

\section{HASIL DAN PEMBAHASAN}

Langkah pertama yang dilakukan adalah menentukan tempat penelitian. Orientasi tempat penelitian dilakukan untuk mengetahui letak dan wilayah penelitian. Penelitian dan pengembangan ini dilakukan di Sekolah Madrasah Tsanawiyah (MTs) yaitu MTs Negeri 2 Bandar Lampung dengan sampel peserta didik kelas VII. Lokasi tempat penelitian beralamat di Jalan Pulau Pisang No. 20, Korpri Raya, Sukarame Kota Bandar Lampung. MTs Negeri 2 Bandar Lampung menerapkan Kurikulum 2013 dan sudah mendapatkan penilaian akreditasi A.

Modul yang dikembangkan dalam penelitian ini menggunakan model penelitian (Borg \& Gall, 1983) yang telah dimodifikasi oleh (Sugiyono, 2015), yaitu potensi dan masalah, mengumpulkan informasi, desain produk, validasi desain, perbaikan desain, uji coba produk, dan revisi produk. Berikut ini hasil pengembangan modul berbasis keterampilan proses sains sebagai bahan ajar pada materi sistem ekskresi pada manusia.

\section{Potensi dan Masalah}

Langkah pertama yaitu potensi dan masalah. Penelitian ini berawal dari potensi atau masalah. Potensi adalah segala sesuatu yang bila didayagunakan akan memiliki nilai tambah, sedangkan masalah merupakan kesenjangan antara harapan dan kenyataaan. Potensi dan masalah yang ada dalam penelitian ini yaitu MTs Negeri 2 Bandar Lampung sudah memiliki sumber belajar yang baik seperti lembar kerja peserta didik LKPD dan buku cetak, namun penggunaannya belum maksimal, karena dalam prosespembelajaran masih berpusat pada guru atau teacher centered sehingga peserta didik tidak terbiasa dengan keterampilan-keterampilan sains dalam pembelajaran. Dalam pelaksanaan pembelajaran IPA sudah selayaknya menerapkan hakekat sains, salah satunya dengan keterampilan-keterampilan sains.

Hasil observasi juga menunjukkan bahwa dalam pembelajaran Biologi pendidik belum optimal dalam menerapkan model pembelajaran yang sesuai dengan hakekat sain, sehingga kemampuan proses sains peserta didik juga belum tergali secara maksimal. Hal ini bertolak belakang dengan potensi yang ada yaitu tersedianya fasilitas sarana dan prasana yang memadai dan ruang Laboratorium yang cukup ideal dalam pembelajaran namun kurang dalam hal pemanfaatan.

Potensi dan masalah tersebut memberikan inspirasi untuk mengembangkan modul berbasis keterampilan proses sains sebagai bahan ajar dalam pembelajaran biologi yang diharapkan nantinya menjadi alat bantu pembelajaran agar memenuhi tujuan pembelajaran peserta didik dikelas VII MTs pada materi sistem ekskresi manusia.

\section{Mengumpulkan Informasi}

Pengumpulan informasi merupakan suatu rancangan atau perencanaan dalam pembuatan produk untuk mengatasi masalah yang ada. Diawali dengan pengumpulan materi-materi, konsep-konsep tentang materi sistem ekskresi pada manusia, mendesain layout, merencanakan kegiatan kerja peserta didik Bahan Ajar yang sesuai dengan keutuhan saat ini yaitu bahan ajar yang mampu menggali dan mengasah keterampilan proses sains, dimana hal ini sejalan dengan kurikulum 2013 dan juga hakekat sains.

\section{Desain Produk}

Desain produk dibuat berdasarkan materi yang telah dipilih dan disesuaikan dengan keterampilan proses sains. Adapun langkah-langkah yang dilakukan dalam mendesain produk berupa modul pembelajaran berbasis keterampilan proses sains sebagai bahan ajar pada materi sistem ekskresi pada manusia adalah sebagai berikut:

Pembuatan Desain Modul

Desain produk adalah suatu gambaran umum desain secara keseluruhan yang akan dimuat di dalam modul pembelajaran. Fungsi desian produk itu sendiri adalah sebagai pedoman atau panduan seperti peta untuk memudahkan proses pembuatan modul. Fungsi umum dari desian produk yaitu sebagai suatu konsep dan ungkapan yang kreatif dalam menyampaikan ide atau gagasan. Pada desain modul juga seseorang dapat menambahkan arahan-arahan seperti arahan letak atau informasi lainnya. Pada tahapan ini pembuatan desain modul sangat penting dalam proses penggunaan layout pada modul yang menggunakan aplikasi desain yaitu corel draw.

Corel draw memiliki kegunaan untuk mengolah gambar, oleh karena itu banyak digunakan pada pekerjaan dalam bidang publikasi atau percetakan ataupun pekerjaan di bidang lain yang membutuhkan proses visualisasi. 
Menetapkan Materi pembelajaran

Penetapan materi pembelajaran ini didapatkan dari hasil observasi di MTs Negeri 2 Bandar Lampung. Berdasarkan hasil observasi, materi sistem ekskresi pada manusia merupakan salah satu materi yang masih mengalami kesulitan dan belum ada penggalian keterampilan proses sains. Kemudian menbuat indikator dan tujuan pembelajaran sesuai dengan Kurikulum 2013.

Penyusunan Lembar Kerja

Lembar Kerja Peserta didik dibuat dan didesain sesuai dengan indikator-indikator dari keterampilan proses sains dan tujuan pembelajaran. Dalam modul ini terdapat 3 LKPD, yaitu (1) penyusunan soal uji kompetensi; (2) penyusunan kunci jawaban; dan (3) penyusunan background, gambar, dan konsepan materi

Pada tahap penyusunan soal uji kompetensi, soal yang akan dimuat dalam modul ini merupakan soal tes pilihan jamak dan essay tentang materi sistem ekskresi pada manusia. Lalu, pada tahap penyusunan kunci jawaban dibuat dibuat sesuai dengan soal uji kompetensi. Kemudian, pengumpulan background, gambar, dan materi adalah dengan cara mengunduh dari berbagai sumber kemudian dibuat dalam format gambar dengan menggunakan Corel Draw X7 Apabila diubah ke dalam format tersebut background gambar akan terlihat memiliki latar belakang yang transparan sehingga membuat media lebih menarik.

\section{Penginstalan Aplikasi Corel Draw X7}

Setelah aplikasi terinstal maka modul siap dibuat pada aplikasi corel draw X7. Adapun yang harus dibuat adalah: Cover depan dan cover belakang modul yang akan dibuat, mendesain modul yang akan dibuat, menyusun materi pembelajaran pada modul, menyusun LKPD, Menyusun soal untuk uji kompetensi

\section{Validasi Produk}

Validasi produk dilakukan dengan cara menghadirkan beberapa pakar atau tenaga ahli yang sudah berpengalaman untuk menilai media pembelajaran yang telah dibuat oleh peneliti. Peneliti meminta penilaian dari dua orang ahli media, dua orang ahli materi, dan dua orang ahli bahasa yang peneliti pilih.Berikut deskripsi hasil validasi oleh ahli media, ahli materi dan ahli bahasa.

\section{Deskripsi Hasil Validasi Desain oleh Ahli Materi}

Validasi ahli materi dilakukan oleh dua orang ahli materi dari dua orang dosen UIN Raden Intan Lampung. Validasi oleh ahli materi dilakukan dalam dua tahap. Hasil validasi ahli materi tahap I dan II dapat dilihat pada Tabel 1

Tabel 1.Tabulasi Uji Ahli Materi 1

\begin{tabular}{lcc}
\hline \multicolumn{1}{c}{ Aspek yangDinilai } & Persentase & Kriteria \\
\hline Aspek Isi & $96 \%$ & Sangat Layak \\
Aspek Kebahasaan & $92 \%$ & Sangat Layak \\
Rata-Rata Persentase & \multicolumn{2}{c}{$94 \%$} \\
Kriteria & \multicolumn{2}{c}{ Sangat Layak } \\
\hline
\end{tabular}

Berdasarkan Tabel 1. menunjukkan bahwa modul berbasis keterampilan proses sains pada materi sistem ekskresi manusia layak digunakan dalam pembelajaran biologi.

Tabel 2. Tabulasi Uji Ahli Materi 2

\begin{tabular}{lcc}
\hline \multicolumn{1}{c}{ Aspek yangDinilai } & Persentase & Kriteria \\
\hline Aspek Isi & $91 \%$ & Sangat Layak \\
Aspek Kebahasaan & $92 \%$ & Sangat Layak \\
Rata-Rata Persentase & \multicolumn{2}{c}{$91 \%$} \\
Kriteria & \multicolumn{2}{c}{ Sangat Layak } \\
\hline
\end{tabular}

Berdasarkan Tabel 2. menunjukkan bahwa modul berbasis keterampilan proses sains pada materi sistem ekskresi manusia layak digunakan dalam pembelajaran biologi. Berdasarkan hasil validasi oleh ahli materi pada validator I adalah sebesar 94\% dalam kategori sangat layak dan pada validator II adalah sebesar 91\% dalam kategori sangat layak. Dapat disimpulkan bahwa modul yang dikembangkan dapat dikatakan baik dan valid dan sudah sesuai dengan jenjang yang menjadi objek sasaran pengembangan.

\section{Deskripsi Hasil Validasi Desain oleh Ahli Desain}

Ahli desain memvalidasi produk berupa modul pembelajaran sebagai bahan ajar untuk pembelajaran biologi, khususnya materi sistem ekskresi pada manusia. Hal ini dilakukan agar hasil modul pembelajaran layak untuk diterapkan dalam proses pembelajaran. Aspek yang dinilai oleh ahli desain media adalah aspek penyajian, kualitas, aspek efektifitas, dan aspek grafika. Adapun validasi ini bertujuan untuk memberikan masukan, informasi, saran dan tanggapan terhadap pengembangan modul berbasis keterampilan proses sains sebagai bahan ajar pada materi sistem sistem ekskresi pada manusia. 
Validasi ahli media dilakukan oleh dua orang dosen dari UIN Raden Intan Lampung. Validator I merupakan dosen jurusan matematika yang memahami macam-macam media pembelajaran dan penggunaannya dalam proses pembelajaran. Validator II merupakan dosen jurusan matematika yang memahami tentang desain dan program dalam suatu media pembelajaran. Validasi dari ahli media hanya dilakukan dalam satu tahap. Hasil validasi dari ahli media dapat dilihat pada Tabel 3 dan Tabel 4.

Tabel 3. Tabulasi Uji Ahli Media I

\begin{tabular}{lcc}
\hline \multicolumn{1}{c}{ Aspek } & Presentase & Kriteria \\
\hline Aspek Kualitas & $73 \%$ & Layak \\
Aspek Efektifitas & $68 \%$ & Layak \\
Aspek Grafika & $73 \%$ & Layak \\
Aspek Penyajian & $65 \%$ & Layak \\
Presentase & \multicolumn{2}{c}{$69 \%$} \\
Kriteria & \multicolumn{2}{c}{ Layak } \\
\hline
\end{tabular}

Berdasarkan Tabel 3. menunjukkan bahwa modul berbasis keterampilan proses sains pada materi sistem ekskresi manusia layak digunakan dalam pembelajaran biologi.

Tabel 4. Tabulasi Uji Ahli Media II

\begin{tabular}{lcc}
\hline \multicolumn{1}{c}{ Aspek } & Presentase & Kriteria \\
\hline Aspek Kualitas & $87 \%$ & Sangat Layak \\
Aspek Efektifitas & $88 \%$ & Sangat Layak \\
Aspek Grafika & $80 \%$ & Sangat Layak \\
Aspek Penyajian & $95 \%$ & Sangat Layak \\
Presentase & \multicolumn{2}{c}{$88 \%$} \\
Kriteria & \multicolumn{2}{c}{ Sangat Layak } \\
\hline
\end{tabular}

Berdasarkan Tabel 4. menunjukkan bahwa modul berbasis keterampilan proses sains pada materi sistem ekskresi manusia layak digunakan dalam pembelajaran biologi. Penilaian oleh validator ahli desain media pada validator I sebesar 69\% dengan kriteria validasi layak, sedangkan validator II sebesar $88 \%$ dengan kriteria validasi sangat layak. Berdasarkan penilaian masing-masing validator media tersebut, dapat dikesimpulan bahwa bahan ajar dinyatakan layak (valid) dan dapat digunakan untuk tahap pengembangan berikutnya.

\section{Deskripsi Hasil Validasi Desain oleh Ahli Bahasa}

Setelah divalidasi oleh ahli media produk berupa modul berbasis keterampilan proses sains pada materi sistem ekskresi kemudian divalidasi oleh ahli bahasa. Hal ini dilakukan untuk melihat kelayakan modul pembelajaran biologi berbasis keterampilan proses sains dari segi penggunaan bahasa dalam modul. Aspek yang dinilai oleh ahli bahasa aspek kualitas penggunaan bahasa dan aspek kesesuaian penempatan kalimat. Tujuan dari validasi ahli bahasa adalah untuk memberikan informasi, masukan, saran dan tanggapan terhadap pengembangan modul berbasis keterampilan proses sains sebagai bahan ajar pembelajaran Biologi pada materi sistem ekskresi manusia.

Validasi bahasa modul pembelajaran direview oleh dua orang dosen dari UIN Raden Intan Lampung. Hasil validasi dari ahli bahasa dapat dilihat pada Tabel 5 dan Tabel 6.

Tabel 5. Tabulasi Uji Ahli Bahasa

\begin{tabular}{lcc}
\hline \multicolumn{1}{c}{ Aspek } & Presentase & Kriteria \\
\hline Aspek Kualitas & $84 \%$ & Layak \\
Penggunaan Bahasa & & \\
Aspek Kesesuaian & $90 \%$ & Sangat \\
Penempatan Kalimat & \multicolumn{2}{c}{ Layak } \\
$\begin{array}{l}\text { Presentase } \\
\text { Kriteria }\end{array}$ & \multicolumn{2}{c}{$86 \%$} \\
\hline
\end{tabular}

Berdasarkan Tabel 5. menunjukkan bahwa modul berbasis keterampilan proses sains pada materi sistem ekskresi manusia layak digunakan dalam pembelajaran biologi.

Tabel 6. Tabulasi Uji Ahli Bahasa

\begin{tabular}{lcc}
\hline \multicolumn{1}{c}{ Aspek } & Presentase & Kriteria \\
\hline Aspek Kualitas & $96 \%$ & Sangat \\
Penggunaan Bahasa & & Layak \\
Aspek Kesesuaian & $95 \%$ & Sangat \\
Penempatan Kalimat & \multicolumn{2}{c}{ Layak } \\
$\begin{array}{l}\text { Presentase } \\
\text { Kriteria }\end{array}$ & \multicolumn{2}{c}{$95 \%$} \\
\hline
\end{tabular}

Berdasarkan Tabel 6. menunjukkan bahwa modul berbasis keterampilan proses sains pada materi sistem ekskresi manusia layak digunakan dalam pembelajaran biologi. Penilaian oleh validator bahasa meliputi aspek kualitas penggunaan bahasa dan aspek kesesuaian penempatan kalimat. Adapun Validator I memberi nilai sebesar $86 \%$ dan pada validator II sebesar $95 \%$. Penilaian validator menilai media yang peneliti kembangkan sudah sangat bagus dan layak.

\section{Revisi Produk}

Hasil validasi oleh para ahli terdapat beberapa saran mengenai modul berbasis keterampilan proses sains yang dibuat peneliti, antara lain adalah terdapat beberapa teks yang terlalu padat dan penjelasan-penjelasan materi kurang ringkas dan jelas. Komentar dan saran tersebut dijadikan acuan untuk merevisi modul yang telah dibuat peneliti. Berikut adalah revisi 


\section{Jurnal Inovasi Pendidikan IPA, 5 (1), 2019 - 84}

Laila Puspita

produk berdasarkan saran ahli materi dan ahli media:

\section{Ahli Materi I}

Berdasarkan lembar instrumen validasi yang telah diberikan peneliti kepada ahli materi I diperoleh hasil agar dilakukan revisi pada penjelasan-penjelasan pada modul agar bahasa yang digunakan lebih ringan dan mudah ditangkap oleh peserta didik serta penambahan materi seperti informasi-informasi terkini tentang sistem ekskresi pada manusia.

\section{Ahli Materi II}

Berdasarkan lembar instrumen validasi yang telah diberikan peneliti kepada ahli materi II diperoleh hasil agar dapat dilakukan revisi pada modul dengan menambahkan peta konsep pada materi sistem sistem ekskresi pada manusia.

\section{Ahli Media I}

Berdasarkan lembar instrumen validasi yang telah diberikan peneliti kepada ahli media I diperoleh hasil agar dilakukan perbaikan pada tampilan cover agar lebih jelas dan penambahan variasi warna pada halaman depan .

\section{Ahli Media II}

Berdasarkan lembar instrumen validasi yang telah diberikan peneliti kepada ahli media I diperoleh hasil bahwa harus menambahkan sumber pada gambar pada setiap materi.

\section{Uji Coba Terbatas}

\section{Data Hasil Uji Coba Terbatas}

Setelah dilakukan validasi oleh ahli media, ahli materi, ahli bahasa, selanjutnya dilakukan uji coba tahap pertama yaitu uji coba terbatas.Uji coba terbatas dimaksudkan untuk memperoleh gambaran untuk mengetahui kualitas modul yang dikembangkan. Uji coba terbatas dilakukan terhadap peserta didik kelas VIII sebanyak 5 orang di MTsN 2 Bandar Lampung (Widyawati $\&$ Prodjosantoso, 2015). Pemilihan peserta didik dilakukan secara random atau acak. Hasil uji coba terbatas mendapatkan persentase $76 \%$ dengan kriteria menarik dapat dilihat pada Tabel 7.

Tabel 7 menunjukkan hasil uji coba lapangan skala terbatas yang di uji coba yang melibatkan 5 peserta didik (Hermawan, Samsuri, Kurniawati, Sofyaningsih, \& Prasetyo, 2018; Widyawati \& Prodjosantoso, 2015). Berdasarkan hasil tersebut diketahui bahwa tanggapan peserta didik pada uji coba terbatas terhadap media pembelajaran biologi keseluruhan diper- oleh rata-rata persentase penilaian sebesar $76 \%$ dengan kriteria menarik. Hal ini dikarenakan bahwa modul yang dikembangkan disukai oleh peserta didik karena menurut peserta didik tampilan modul biologi yang sangat menarik dan tidak membosankan, selain itu peserta didik lebih bisa mandiri dalam pembelajaran karena banyak keterampilan proses sains yang dikembangkan.

Tabel 7. Tabulasi Hasil Uji Coba Lapangan Terbatas

\begin{tabular}{|c|c|c|c|}
\hline No. & $\begin{array}{c}\text { Nama Inisial } \\
\text { Responden }\end{array}$ & $(\%)$ & Kriteria \\
\hline 1. & A & $85 \%$ & Sangat Menarik \\
\hline 2. & B & $81 \%$ & Menarik \\
\hline 3. & $\mathrm{C}$ & $85 \%$ & Sangat Menarik \\
\hline 4. & $\mathrm{D}$ & $65 \%$ & Menarik \\
\hline 5. & $\mathrm{E}$ & $65 \%$ & Menarik \\
\hline \multicolumn{2}{|c|}{ Rata-Rata Persentase } & & $76 \%$ \\
\hline \multicolumn{2}{|c|}{ Kriteria } & & Menarik \\
\hline
\end{tabular}

\section{Revisi Hasil Uji Coba Lapangan Terbatas}

Pada uji coba lapangan terbatas tidak terlalu banyak ditemukan kritik dan saran dari peserta didik. Beberapa dari peserta didik menilai bahwa gambar yang terdapat pada modul kurang jelas, sehingga gambar terlihat buram. Tanggapan ini menjadi masukan bagi peneliti sehingga produk direvisi dengan memperbaiki resolusi gambar. Menurut para peserta didik pada uji coba lapangan terbatas, modul yang dikembangkan sudah menarik.

\section{Uji Coba Secara Lebih Luas}

\section{Data Hasil Uji Coba Lebih Luas}

Setelah dilakukan uji coba terbatas dan dilakukan perbaikan pada resolusi gambar dalam modul dan penambahan materi pada modul, maka tahap selanjutnya adalah uji coba lebih luas. Uji coba ini dilakukan pada peserta didik kelas VIII di MTs Negeri 2 Bandar Lampung sebanyak 33 orang peserta didik. Uji coba produk secara luas dengan tujuan untuk mengetahui respon peserta didik terhadap produk dan mengetahui bagaimana kelayakan produk modul berbasis keterampilan proses sains pada materi sistem ekskresi pada manusia. Hasil uji coba lebih luas dapat dilihat pada Tabel 8. Tabel 8 menunjukkan hasil uji coba lapangan skala luas. Berdasarkan Tabel 8 dapat dilihat bahwa rata-rata persentase sebesar $72 \%$ dengan kriteria menarik.

\section{Revisi Hasil Uji Coba Lebih Luas}

Revisi hasil uji coba lebih luas merupakan tahapan terakhir dalam penelitian ini. Pada hasil 


\section{Jurnal Inovasi Pendidikan IPA, 5 (1), 2019 - 85}

Laila Puspita

uji coba lebih luas tidak ditemukan kritik dan saran dari peserta didik. Pada uji coba skala luas, bahan ajar berupa modul pembelajaran berbasis keterampilan proses sains yang dikembangkan memperoleh penilaian menarik dengan persentase $72 \%$. Hasil ini menunjukkan bahwa modul pembelajaran berbasis keterampilan proses sains menarik dan layak untuk dijadikan sebagai bahan ajar untuk peserta didik kelas VIII pada materi sistem ekskresi pada manusia.

Tabel 8. Tabulasi Hasil Uji Coba Lebih Luas

\begin{tabular}{|c|c|c|c|}
\hline No. & Inisial Responden & $\%$ & Kriteria \\
\hline 1. & $\mathrm{~F}$ & $78 \%$ & Sangat Menarik \\
\hline 2. & G & $78 \%$ & Sangat Menarik \\
\hline 3. & $\mathrm{H}$ & $77 \%$ & Sangat Menarik \\
\hline 4. & I & $60 \%$ & Menarik \\
\hline 5. & $\mathbf{J}$ & $76 \%$ & Sangat Menarik \\
\hline 6. & K & $71 \%$ & Menarik \\
\hline 7. & $\mathrm{~L}$ & $63 \%$ & Menarik \\
\hline 8. & M & $57 \%$ & Menarik \\
\hline 9. & $\mathrm{~N}$ & $65 \%$ & Menarik \\
\hline 10. & $\mathrm{O}$ & $88 \%$ & Sangat Menarik \\
\hline 11. & $\mathrm{P}$ & $63 \%$ & Menarik \\
\hline 12. & Q & $73 \%$ & Menarik \\
\hline 13. & $\mathrm{R}$ & $63 \%$ & Menarik \\
\hline 14. & S & $63 \%$ & Menarik \\
\hline 15. & $\mathrm{~T}$ & $65 \%$ & Menarik \\
\hline 16. & $\mathrm{U}$ & $85 \%$ & Sangat Menarik \\
\hline 17. & V & $80 \%$ & Sangat Menarik \\
\hline 18. & $\mathrm{~W}$ & $80 \%$ & Sangat Menarik \\
\hline 19. & $\mathrm{X}$ & $79 \%$ & Sangat Menarik \\
\hline 20. & Y & $79 \%$ & Sangat Menarik \\
\hline 21. & $\mathrm{Z}$ & $66 \%$ & Menarik \\
\hline 22. & AA & $80 \%$ & SangatMenarik \\
\hline 23. & $\mathrm{AB}$ & $59 \%$ & Menarik \\
\hline 24. & $\mathrm{AC}$ & $67 \%$ & Menarik \\
\hline 25. & $\mathrm{AD}$ & $86 \%$ & Sangat Menarik \\
\hline 26. & $\mathrm{AE}$ & $62 \%$ & Menarik \\
\hline 27. & $\mathrm{AF}$ & $69 \%$ & Menarik \\
\hline 28. & $\mathrm{AG}$ & $74 \%$ & Menarik \\
\hline 29. & $\mathrm{AH}$ & $81 \%$ & Sangat Menarik \\
\hline 30. & AJ & $65 \%$ & Menarik \\
\hline 31. & AI & $60 \%$ & Menarik \\
\hline 32. & $\mathrm{AK}$ & $84 \%$ & Sangat Menarik \\
\hline 33. & AL & $84 \%$ & Sangat Menarik \\
\hline \multicolumn{3}{|c|}{ Rata-rata Persentase } & $72 \%$ \\
\hline \multicolumn{2}{|c|}{ Kriteria } & & Menarik \\
\hline
\end{tabular}

Penelitian pengembangan ini menghasilkan produk berupa modul berbasis keterampilan proses sains sebagai bahan ajar pada pembelajaran Biologi dalam materi sistem ekskresi pada manusia. Dalam Proses Pembelajaran selalu memiliki ujuan pembelajaran, salah satu cara untuk mencapai tujuan tersebut dengan menggunakan bahan ajar yang tepat dan sesuai dengan hakekat pembelajaran dan kurikulum yang dipakai. Dalam hal ini peneliti menggunakan kete- rampilan proses sains dalam basis pembuatan modul karena keterampilan ini sangat relevan dengan tuntutan kurikulum dan hakekat pembelajaran sains. Aydinli menyatakan bahwa kurikulum menyarankan bahwa banyak aktivitas sains membutuhkan keterampilan proses sains (Fithriyyati \& Maryani, 2018; Rosa, 2015). Pernyataan Aydinli didukung oleh Anderson menyatakan bahwa keterampilan proses sains merupakan bagian penting dari penyelidikan ilmiah (Sakinah, Sahputra, \& Putra, 2018).

Penelitian yang dilakukan oleh Liyan juga menyatakan bahwa modul dapat digunakan sebagai bahan ajar ataupun media pembelajaran yang efektif bagi peserta didik (Rizqi, Parmin, \& Nurhayati, 2013). Selain itu modul berperan sebagai petunjuk mengajar yang efektif bagi pendidik serta menjadi bahan untuk melatih kemampuan peserta didikdalam kegiatan belajar secara mandiri. Modul yang dibuat didesain untuk melatih belajar mandiri peserta didik, didalam modul disediakan petunjuk peggunaan modul untuk membimbing peserta didik dalam belajar mandiri. Diawali dengan Adanya kompetensi yang harus dicapai dilanjutkan dengan adanya peta konsep. Peta konsep akan membuat peserta didik secara otomatis mengetahui gambaran materi pembelajaran yang ada dalam modul.

Modul pembelajaran sebagai bahan ajar ini didesain untuk menyajikan materi mengenai bab sistem ekskresi pada manusia yang dilandaskan pada keterampilan proses sains sehingga akan menambah keterampilan peserta didik dalam menerapakan sains, hal ini juga didukung oleh penelitian (Suryani, 2015) bahwa modul dalam konteks ini adalah modul yang merupakan media yang digunakan sebagai alat untuk memahami materi biologi, sekaligus dapat memberikan kesenangan dalam belajar mata pelajaran biologi. Depdiknas juga menyatakan bahwa keterampilan proses sains dapat dijadikan pedoman dalam pengembangan beberapa keterampilan peserta didik, yaitu berupa keterampilan fisik, intelektual dan sosial (Arsih, 2016). Sehingga diharapkan peserta didik memiliki kemandirian dalam belajar karena memiliki keahlian dalam berbagai keterampilan sains. Hal ini juga didukung dari penelitian yang telah dilakukan oleh (Rosa, 2015) yaitu modul yang dikembangkan berbasis keterampilan proses sains, yang meliputi mengamati, mengklarifikasi, mengkomunikasi, mengukur, memprediksi dan menyimpulkan. Hasil penelitian menunjukkan bahwa terdapat peningkatan hasil belajar serta peningkatan keterampilan proses 
sains peserta didik (Rosa, 2015). Hasil penelitian menunjukkan bahwa modul sangat membantu peserta didik belajar mandiri, membantu dan diperlukan peserta didik sebagai panduan belajar dimana dilengkapi dengan eksperimeneksperimen sederhana (Rosa, 2015).

Keterampilan proses sains dalam modul pembelajaran biologi pada materi sistem ekskresi pada manusia yang dikembangkan ini, disisipkan kedalam eksperimen-eksperimen sederhana yang bisa dilakukan oleh peserta didik secara mandiri. Penelitian ini dukung juga oleh penelitian (Mei, Kaling, Xinyi, Sing, \& Khoon, 2007) yang menyatakan bahwa adanya peningkatan yang signifikan mengenai kompetensi keterampilan proses sains dan memiliki presentase yang tinggi dalam keterampilan proses menujukan bahwa peserta didik lebih memiliki tingkat sadar mengenai relevansi dari sains dalam kehidupan peserta didik.

\section{SIMPULAN}

Simpulan dari hasil penelitian ini, modul berbasis keterampilan proses sains (link: http://bit.ly/ModulLaila) sebagai bahan ajar pembelajaran biologi pada materi sistem ekskresi manusia layak dan menarik untuk digunakan dalam kegiatan pembelajaran.

\section{DAFTAR PUSTAKA}

Ainin, M. (2013). Penelitian pengembangan dalam pembelajaran bahasa Arabi. OKARA: Jurnal Bahasa Dan Sastra, 7(2). https://doi.org/10.19105/OJBS.V7I2.449

Akbar, R. R. A., \& Komarudin, K. (2018). Pengembangan video pembelajaran matematika berbantuan media sosial instagram sebagai alternatif pembelajaran. Desimal: Jurnal Matematika, 1(2), 209. https://doi.org/10.24042/djm.v1i2.2343

Anggraini, A., \& Sukardi, S. (2015).

Pengembangan modul prakarya dan kewirausahaan materi pengolahan berbasis product oriented bagi peserta didik SMK. Jurnal Pendidikan Vokasi, 5(3), 287-296. https://doi.org/10.21831/jpv.v5i3.6484

Anwar, I. (2010). Pengembangan bahan ajar. Bahan Kuliah Online Direktori UPI. Bandung.

Arsih, F. (2016). Pengembangan LKS IPA Biologi kelas VIII SMP berorientasi pada pendekatan keterampilan proses sains. Ta'dib, 13(1). https://doi.org/10.31958/jt.v13i1.170
Borg, W. R., \& Gall, M. D. (1983). Educational research: An introduction. New York: Longman.

Dewi, I., \& Lisiani, S. (2015). Upaya meningkatkan kreativitas matematis siswa Sekolah Menengah Pertama Negeri 5 Terbuka Medan dengan menggunakan modul model learning cycle. Jurnal Didaktik Matematika, 2(1). Retrieved from http://www.jurnal.unsyiah.ac.id/DM/article /view/2382

Dewi, P. Y. A., \& Primayana, K. H. (2019). Effect of learning module with setting contextual teaching and learning to increase the understanding of concepts. International Journal of Education and Learning, 1(1), 19-26. https://doi.org/10.31763/ijele.v1i1.26

Fithriyyati, N., \& Maryani, I. (2018). Science lesson plan evaluation for 7 th grade secondary school: A learning process reflection. Psychology, Evaluation, and Technology in Educational Research, 1(1), 9-18. https://doi.org/10.33292/petier.v1i1.17

Gall, M. D., Gall, J. P., \& Borg, W. R. (2007). Educational research: An introduction. Boston: Pearson/Allyn \& Bacon.

Hermawan, H., Samsuri, S., Kurniawati, D. P., Sofyaningsih, V., \& Prasetyo, D. (2018). The use of the controversial public issue learning model with videos and a macromedia flash player on Civic Education. Psychology, Evaluation, and Technology in Educational Research, 1(1), 19-30. https://doi.org/10.33292/petier.v1i1.2

Marjan, J., Arnyana, I. B. P., \& Setiawan, I. G. A. N. (2014). Pengaruh pembelajaran pendekatan saintifik terhadap hasil belajar biologi dan keterampilan proses sains siswa MA. Mu allimat NW Pancor Selong Kabupaten Lombok Timur Nusa Tenggara Barat. Jurnal Pendidikan Dan

Pembelajaran IPA Indonesia, 4(1).

Retrieved from http://oldpasca.undiksha.ac.id/ejournal/index.php/jurnal_ipa/article/view/1 316

Mei, Y. T. G., Kaling, C., Xinyi, C. S., Sing, J. S. K., \& Khoon, K. N. S. (2007).

Promoting science process skills and the relevance of science through science alive 


\section{Jurnal Inovasi Pendidikan IPA, 5 (1), 2019 - 87}

Laila Puspita

programme. In Proceedings of the

Redesigning Pedagogy: Culture,

Knowledge and Understanding

Conference, Singapore.

Nafaida, R., Halim, A., \& Rizal, S. (2015).

Pengembangan modul berbasis phet untuk meningkatkan pemahaman konsep dan motivasi belajar siswa pada materi pembiasan cahaya. Jurnal Pendidikan Sains Indonesia (Indonesian Journal of Science Education), 3(1), 181-185.

Retrieved from

http://www.jurnal.unsyiah.ac.id/JPSI/articl e/view/7663

Noto, M. S. (2014). Perangkat pembelajaran matematika berbasis SMART (Specific, measurable, achievable, realistic, and timebound). Infinity Journal, 3(1), 18-32. https://doi.org/10.22460/infinity.v3i1.p1832

Putra, R. W. Y., \& Anggraini, R. (2016). Pengembangan bahan ajar materi trigonometri berbantuan software iMindMap pada siswa SMA. Al-Jabar : Jurnal Pendidikan Matematika, 7(1), 3947. https://doi.org/10.24042/ajpm.v7i1.129

Rizqi, A. M., Parmin, P., \& Nurhayati, S. (2013). Pengembangan modul IPA terpadu berkarakter tema pemanasan global untuk siswa SMP/MTs. Unnes Science Education Journal, 2(1), 03-208. https://doi.org/10.15294/usej.v2i1.1824

Rodiawati, H., \& Komarudin, K. (2018). Pengembangan e-learning melalui modul interaktif berbasis learning content development system. Jurnal Tatsqif, 16(2), 172-185.

https://doi.org/10.20414/jtq.v16i2.190

Rosa, F. O. (2015). Pengembangan modul pembelajaran IPA SMP pada materi tekanan berbasis keterampilan proses sains. Jurnal Pendidikan Fisika, 3(1). https://doi.org/10.24127/jpf.v3i1.21

Rosidi, I. (2016). Pengembangan lembar kegiatan siswa berorientasi pembelajaran penemuan terbimbing (guided discovery learning) untuk melatihkan keterampilan proses sains. Jurnal Pena Sains, 3(1), 10. https://doi.org/10.21107/jps.v3i1.1554

Sakinah, N., Sahputra, R., \& Putra, R. (2018). Deskripsi keterampilan proses sains mahasiswa pendidikan kimia FKIP Untan pada materi sifat koligatif larutan. Jurnal Pendidikan Dan Pembelajaran, 7(5).

Sasanti, M., Hartini, S., \& Mahardika, A. I. (2017). Pengembangan LKS dengan model inquiry discovery learning (IDL) untuk melatihkan keterampilan proses sains pada pokok bahasan listrik dinamis. Berkala Ilmiah Pendidikan Fisika, 5(1), 46-59. https://doi.org/10.20527/bipf.v5i1.2815

Septina, N., Farida, F., \& Komarudin, K. (2018). Pengembangan lembar kerja siswa dengan pendekatan saintifik berbasis kemampuan pemecahan masalah. Jurnal Tatsqif, 16(2), 160-171.

https://doi.org/10.20414/jtq.v16i2.200

Shinta, R. N. (2014). Pengembangan modul pembelajaran penjumlahan dan pengurangan bilangan bulat dengan pendekatan CTL berdasarkan Kurikulum 2013. Mimbar Sekolah Dasar, 1(2), 142147. https://doi.org/10.17509/mimbarsd.v1i2.875

Subekti, T. (2018). Pengembangan modul bahasa Indonesia bermuatan nilai karakter kebangsaan bagi mahasiswa PGSD. Profesi Pendidikan Dasar, 3(2), 88. https://doi.org/10.23917/ppd.v3i2.2746

Sugiyono, S. (2015). Metode penelitian dan pengembangan. Bandung: Alfabeta.

Suryani, I. F. (2015). Pengembangan Majalah Biore (Biologi Reproduksi) submateri kelainan dan penyakit pada sistem reproduksi sebagai sumber belajar mandiri siswa SMA/MA. In Seminar Nasional dan Call for Paper Ke-2 Tentang

"Pengintegrasian Nilai Karakter Dalam Pembelajaran Kreatif di Era Masyarakat Ekonomi ASEAN.

Widyasari, A., Sukarmin, S., \& Sarwanto, S. (2015). Pengembangan modul fisika kontekstual pada materi usaha, energi, dan daya untuk peserta didik kelas X SMK Harapan Kartasura. Inkuiri, 4(2), 125-134 $-134$.

Widyawati, A., \& Prodjosantoso, A. K. (2015). Pengembangan media komik IPA untuk meningkatkan motivasi belajar dan karakter peserta didik SMP. Jurnal Inovasi Pendidikan IPA, 1(1), 24-35. https://doi.org/10.21831/JIPI.V1I1.4529 